\title{
Mechanism of Iron Oxide Reduction with Hydrogen/Carbon Monoxide Mixtures*
}

\author{
By A. A. El-GEASSY,** K. A. SHEHATA** and S. Y. EZZ***
}

\begin{abstract}
Synopsis
Pure iron oxide briquettes, having different grain size and porosity, indurated at different temperatures, were reduced with $\mathrm{H}_{2}, \mathrm{CO}$ and mixtures of both gases which are representing reformed natural gas, over the temperature range of $800^{\circ}$ to $1100^{\circ} \mathrm{C}$. The reduction mechanism deduced from activation energy calculations, microscopic examination, chemical and $X$-ray analysis, was found to depend mainly on the original structure of the briquette and the reducing gas composition.

Reduction of dense briquettes with $\mathrm{H}_{2}$ is controlled by the chemical reaction and becomes mixed controlled by both the chemical reaction and gaseous diffusion for reduction with either $\mathrm{CO}$ or $\mathrm{CO} / \mathrm{H}_{2}$ mixtures, with more contribution of the gaseous diffusion part as the $\mathrm{CO}$ ratio in the gas increases. Rcduction of porous briquettes is diffusion controlled for all gases. Rate minima for porous briquettes were detected at $975^{\circ} \mathrm{C}$ for $\mathrm{CO}$ reduction and at $1025^{\circ} \mathrm{C}$ for $\mathrm{CO} / \mathrm{H}_{2}$ mixtures. The overall reduction rate exponentially varied with gas composition.
\end{abstract}

\section{Introduction}

In view of the abandant and cheap reserves of natural gas in many parts of the world and due to its economical and technical advantages in reducing iron ores, many gaseous direct reduction processes are now well developed on industrial scale. On the other hand, the continuous decrease in the world reserves of suitable metallurgical coke and the increase in its prices add problems to the use of the traditional blast furnace, especially in countries lacking in coking coals.

The present investigation is a trial for understanding the reduction mechanism of fired hematite briquettes, of low and high porosity, during reduction with $\mathrm{H}_{2} / \mathrm{CO}$ mixtures which are the constituents of reformed natural gas.

The complexity of the reduction process combined with the fact that under different experimental conditions the controlling stage of the reduction process may not be necessarily the same, has led workers in this field to a wide diversity of opinions regarding the reduction mechanism. Some authors studied gas diffusion controlled reactions, ${ }^{1-9)}$ solid-state diffusion controlled reactions ${ }^{10-12)}$ and chemically controlled reactions. ${ }^{13)}$ Many others derived mathematical models describing the reduction process, ${ }^{\mathbf{1 4}-20}$ ) but most of them are limited for certain conditions. Reduction with $\mathrm{H}_{2},{ }^{5-13)} \mathrm{CO},{ }^{21-24)}$ mixtures of both gases ${ }^{25-28)}$ and natural gas ${ }^{29,30)}$ were also studied.

\section{Experimental}

Chemically pure iron oxide was used to avoid side effects arising from other ingradients in the ore. The method of preparation of briquettes, their firing and porosity measurements were given in a previous paper. ${ }^{31)}$ Characteristics of the briquettes are shown in Table 1.

A weight-loss method was used for accurate determination of the course of reduction. The reduction system was as described previously, ${ }^{31)}$ except for the addition of a purification system for CO. The total gas flow rate for pure gases or for mixtures is $1 \mathrm{l} / \mathrm{min}$. Analysis of carbon in reduced briquettes was carried out by the ignition method (using Carbon \& Sulphur Apparatus, Strölein, W. Germany).

\section{Results and Discussion}

Two types of briquettes were used in the present investigation, the dense, having $7 \%$ porosity and constitutes of about $200 \mu$ particles sintered together; the other is porous, $35 \%$ porosity and $100 \mu$ particles. These two materials were reduced with $\mathrm{CO}$ or 25, 50 and $75 \%$ mtxtures of $\mathrm{CO} / \mathrm{H}_{2}$. Reduction with $\mathrm{H}_{2}$ was extensively studied in a previous paper, ${ }^{31)}$ and will be considered here for comparison.

\section{Reduction of Dense Briquettes}

\section{Rate of Reduction}

Figure 1 represents the reduction curves of dense $\mathrm{Fe}_{2} \mathrm{O}_{3}$ briquettes with $\mathrm{CO}$. It shows that reduction stops at about $40 \%$ at $700^{\circ} \mathrm{C}$ and at $85 \%$ at $800^{\circ} \mathrm{C}$, but is complete at higher temperatures. Incomplete reduction at low temperatures is ascribed to the great amounts of carbon deposited on the surface of the briquettes, which seal up the porosity preventing diffusion of the gas.

By adding $\mathrm{H}_{2}$ to $\mathrm{CO}$ the reduction rate was improved as indicated by Fig. 2, which is a plot of initial reduction rates against gas composition. An example for the reduction curves obtained for gas mixtures is given in Fig. 3. Incomplete reduction is also observed at $700^{\circ}$ and $800^{\circ} \mathrm{C}$ but at higher reduction extents as compared with $\mathrm{CO}$ reduction.

Table 1. Characteristics of $\mathrm{Fe}_{2} \mathrm{O}_{3}$ briquettes

\begin{tabular}{l|ccccc}
\hline Sample & $\begin{array}{c}\text { Firing } \\
\text { Temp. } \\
\left({ }^{\circ} \mathrm{C}\right)\end{array}$ & $\begin{array}{c}\text { Diameter } \\
(\mathrm{mm})\end{array}$ & $\begin{array}{c}\text { Height } \\
(\mathrm{mm})\end{array}$ & $\begin{array}{c}\text { Total } \\
\text { porosity } \\
(\%)\end{array}$ & $\begin{array}{c}\text { Mean } \\
\text { grain } \\
\text { diameter } \\
(\mathrm{mm})\end{array}$ \\
\hline Green & 110 & 12.3 & 13.4 & 50 & 0.33 \\
Porous & 850 & 10.8 & 12.2 & 35 & 1.04 \\
Dense & 1000 & 9.8 & 11.1 & 7 & 2.10 \\
\hline
\end{tabular}

* Received October 2, 1976.

** Department of Metallurgy, National Research Center, Dokki, Cairo, A.R. Egypt.

*** Faculty of Engineering, Cairo University, Cairo, A.R. Egypt. 


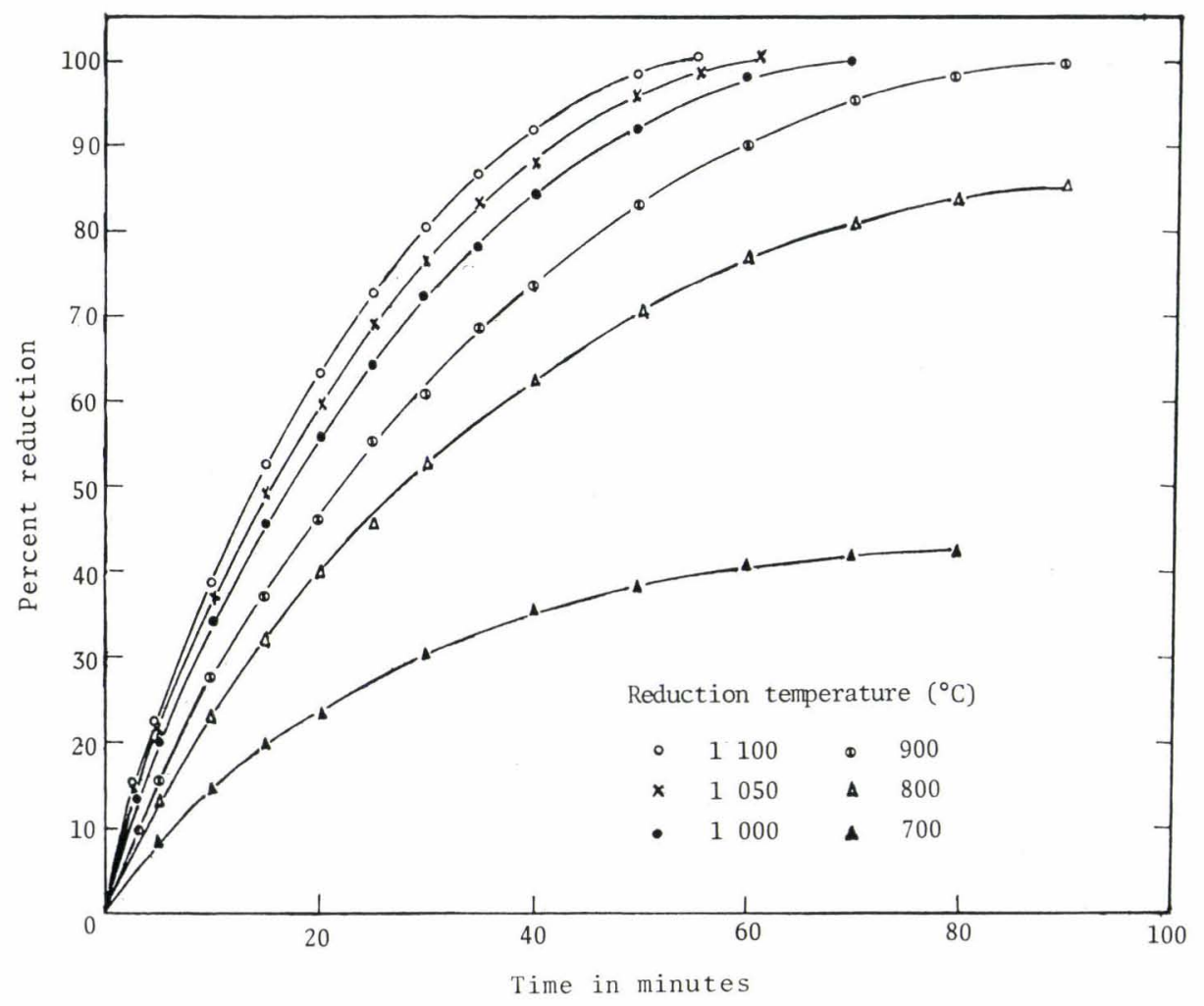

Fig. 1. Reduction curves of dense briquettes with $\mathrm{CO}$

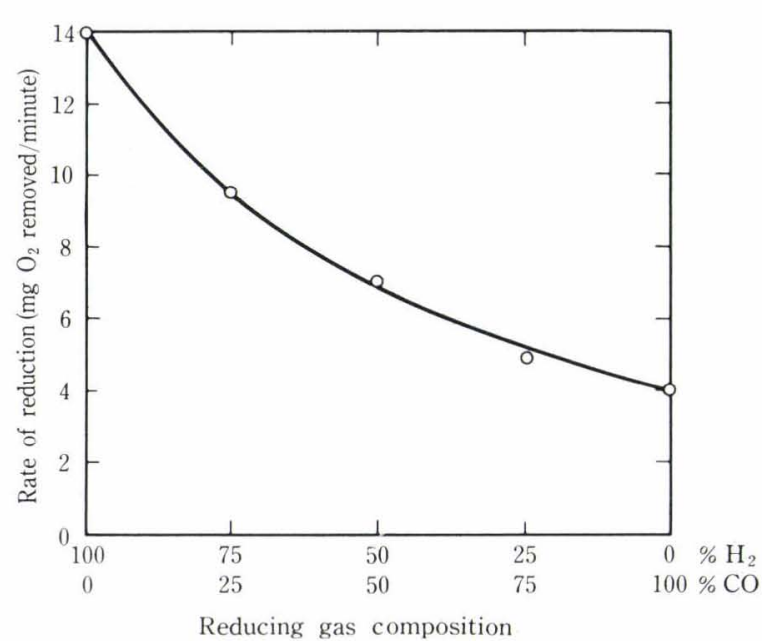

Fig. 2. Effect of gas composition on the rate of reduction of dense briquettes at $1000^{\circ} \mathrm{C}$

Comparing with $\mathrm{H}_{2}$ reduction, ${ }^{31)}$ it is clear that $\mathrm{H}_{2}$ gives faster reduction rates than $\mathrm{CO}$, and by mixing the two gases the rates are intermediate. Thermodynamically, $\mathrm{H}_{2}$ reduces $\mathrm{Fe}_{2} \mathrm{O}_{3}$ more easily than $\mathrm{CO}$ as revealed by the free energy changes calculated for both cases (Table 2). ${ }^{32)}$

For reduction with gas mixtures, the relative contribution of each gas to the overall reduction rate depends on the activity of its molecules and their selective adsorption on the iron oxide surface.

\section{Temperature Effect on the Reduction Rate}

Turkdogan and Vinters ${ }^{33}$ ) found that the measured overall reduction rate is not equivalent to the specific rate of the chemical reaction but it also depends on the active surface area of the oxide and the diffusion

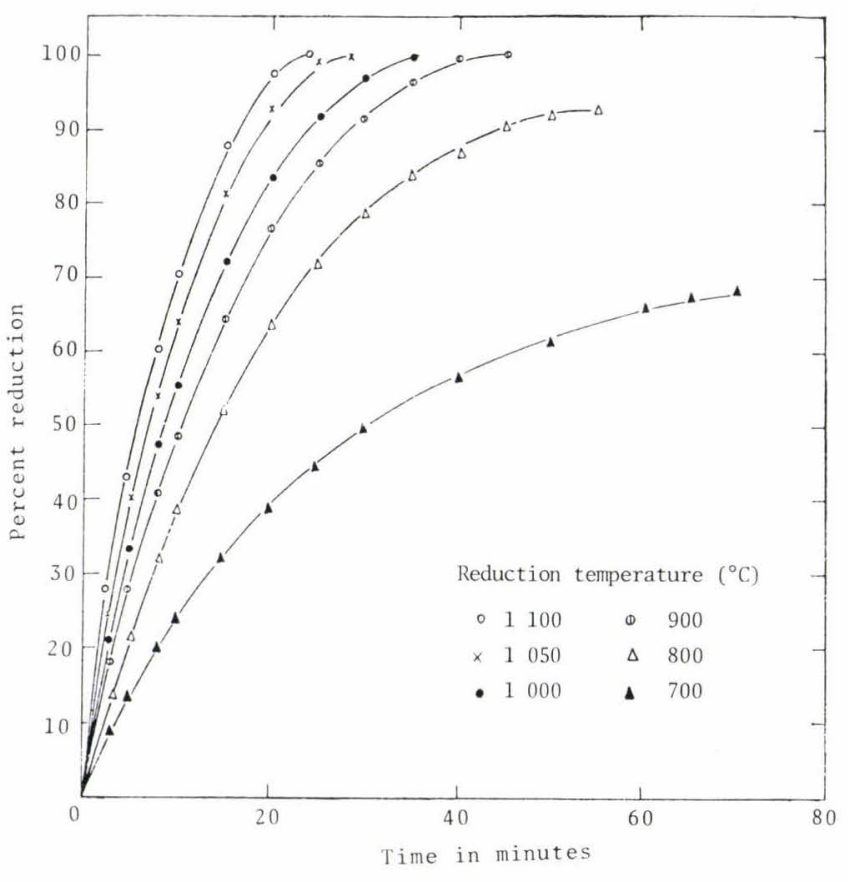

Fig. 3. Reduction curves of dense briquettes with a $50 \% \mathrm{CO} / \mathrm{H}_{2}$ mixture

coefficient of the reducing gas. Accordingly, activation energy values obtained from plots of the overall reduction rate against reciprocal of absolute temperature, does not necessarily correspond to the specific rate of chemical reaction but more reasonably to whatever process is controlling. Strangway ${ }^{34)}$ could classify apparent activation energies for the reduction of iron oxide in ranges corresponding to the rate controlling process. 
Figure 4 presents Arrhenius plots for the reduction of dense briquettes* with different gas compositions. The activation energy values assessed from these lines varied according to the gas composition as shown in Table 3, which implies the variation of the rate controlling process with gas composition.

\section{Microscopic Examination}

Partially reduced briquettes reveal the lack of sharp boundaries between phases which interfere in rather wide bands. (Hematite and magnetite will not be included in this investigation since the transformation of wustite to iron is considered as rate controlling). Photograph 1(a) represents the iron-wustite intergrowth in a briquette partially reduced with a $50 \%$ $\mathrm{CO} / \mathrm{H}_{2}$ mixture. It shows irregular growth of iron within the wustite phase which is highly porous. This does not significantly differ from the structure of $\mathrm{CO}$ reduced briquettes. On the other hand, $\mathrm{H}_{2}$ reduction showed that wustite patches are surrounded by iron layers ${ }^{31)}$ in a shrinking core type of reaction.

It is also observed that for reduction with $\mathrm{CO}$ or $\mathrm{CO} / \mathrm{H}_{2}$ mixtures, the iron phase always consists of two zones (Photo. $1(\mathrm{~b})$ ), the outer is more porous and is mainly iron carbide (as will be shown by X-ray analysis), the inner being iron. For $\mathrm{H}_{2}$ reduction, one iron zone is usually detected.

Table 2. Standard free energy changes for reduction of $\mathrm{Fe}_{2} \mathrm{O}_{3}$ with $\mathrm{H}_{2}$ and $\mathrm{CO}$ at $1000^{\circ} \mathrm{C}$

\begin{tabular}{c|c} 
Reaction & $\Delta \mathrm{F}^{\circ}(\mathrm{kcal})$ \\
\hline $\mathrm{Fe}_{2} \mathrm{O}_{3}+3 \mathrm{H}_{2}=2 \mathrm{Fe}+3 \mathrm{H}_{2} \mathrm{O}$ & -36.00 \\
$\mathrm{Fe}_{2} \mathrm{O}_{3}+3 \mathrm{CO}=2 \mathrm{Fe}+3 \mathrm{CO}_{2}$ & -31.00 \\
\hline
\end{tabular}

Table 3. Activation energies for reduction of dense briquettes Reducing gas $E(\mathrm{kcal} / \mathrm{mol})$

\begin{tabular}{r|r}
$100 \% \mathrm{CO}$ & 7.55 \\
$75 \% \mathrm{CO}+25 \% \mathrm{H}_{2}$ & 8.94 \\
$50 \% \mathrm{CO}+50 \% \mathrm{H}_{2}$ & 9.59 \\
$25 \% \mathrm{CO}+75 \% \mathrm{H}_{2}$ & 10.83 \\
$100 \% \mathrm{H}_{2}{ }^{31)}$ & 12.80
\end{tabular}

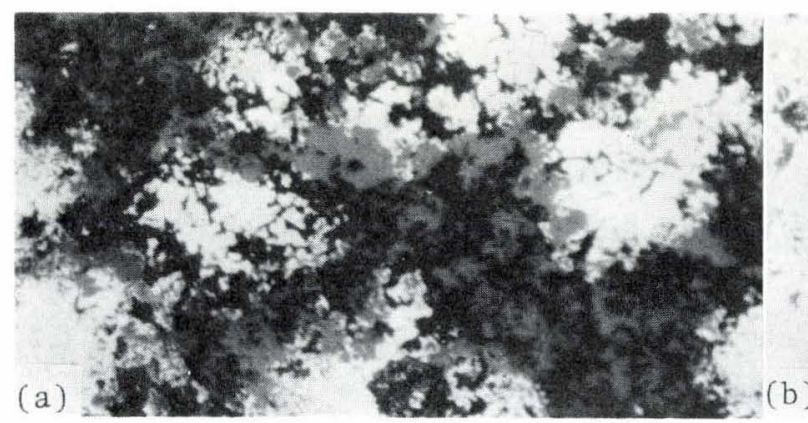

(a) Wustite-iron intergrowth

\section{Mechanism of Reduction}

For $\mathrm{H}_{2}$ reduction the initial parts of the reduction curves are mostly linear (up to $50 \sim 90 \%$ reduction depending on temperature) indicating a constant rate of reduction. ${ }^{31)}$ The activation energy value obtained for this case $(12.8 \mathrm{kcal} / \mathrm{mol})$ indicated a chemically controlled process. However, linear rates here are mainly chemical rates witheut interference of diffusion resistances which may change the rates. As the microstructure showed the formation of iron layer around wustitute particles, this may also explain that reduction is chemically controlled till a dense iron layer is formed and prevents gas diffusion. ${ }^{31)}$

On the other hand, reduction with $\mathrm{CO}$ shows gradual decrease in the rate with progress of reduction (Fig. 1) revealing the creation of an increasing resistance to the chemical reaction. The activation energy value reported for $\mathrm{CO}$ reduction signifies a mixed controlled process by both the chemical reaction and gaseous diffusion. ${ }^{35)}$ The decreasing rate with progress of reduction in this case is due to diffusion of gases through an increasing thickness of a porous iron layer. During reduction with $\mathrm{CO}$, other side reactions occur between the iron phase and $\mathrm{CO}$ gas

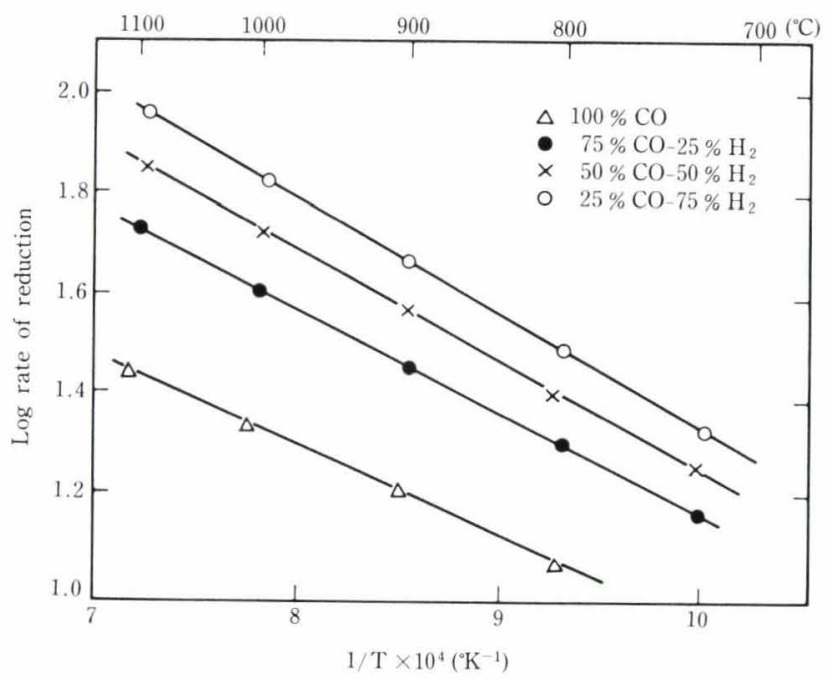

Fig. 4. Arrhenius plots for the reduction of dense briquettes

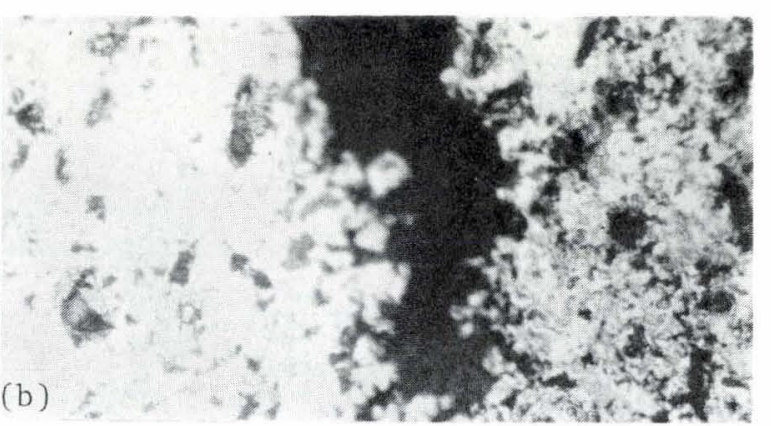

(b) Left: the inner dense iron zone Right: the outer porous iron carbide

Photo. 1. Photomicrographs for a dense briquette, $60 \%$ reduced at $1000^{\circ} \mathrm{C}$ with a $50 \% \mathrm{CO} / \mathrm{H}_{2} \mathrm{mixture}(\times 900)(\times 4 / 5)$

\footnotetext{
The rates of reduction were taken at $50 \%$ reduction to avoid errors of measuring initial rates and to correspond to the wustite-iron transformation.
} 
or deposited active carbon which result in the formation of iron carbide. These additional reactions would change the reduction mechanism, especially from the point of gaseous diffusion through the porous iron carbide layer formed (Photo. 1(b)).

For $\mathrm{CO} / \mathrm{H}_{2}$ reduction, as the rates are intermediate between those for reduction with pure gases, it would be expected that the rate controlling process in this case will also be a combination of those prevailing in reduction with pure gases. However, the activation energy values obtained for $\mathrm{CO} / \mathrm{H}_{2}$ mixtures reveal also a mixed controlled process ${ }^{34)}$ with more contribu- tion of the gaseous diffusion factor as the $\mathrm{CO}$ ratio in the mixture increases. This is reasonable since as the $\mathrm{CO}$ ratio increases, the greater will be the amount of iron carbide formed and hence the greater will be the resistance to diffusion of gases.

\section{Reduction of Porous Briquettes}

\section{Rate of Reduction}

Porous briquettes give faster reduction rates than dense briquettes due to larger surface area. Figures 5 and 6 represent the reduction curves with $\mathrm{CO}$ and a $50 \% \mathrm{CO} / \mathrm{H}_{2}$ mixture. Both figures show that

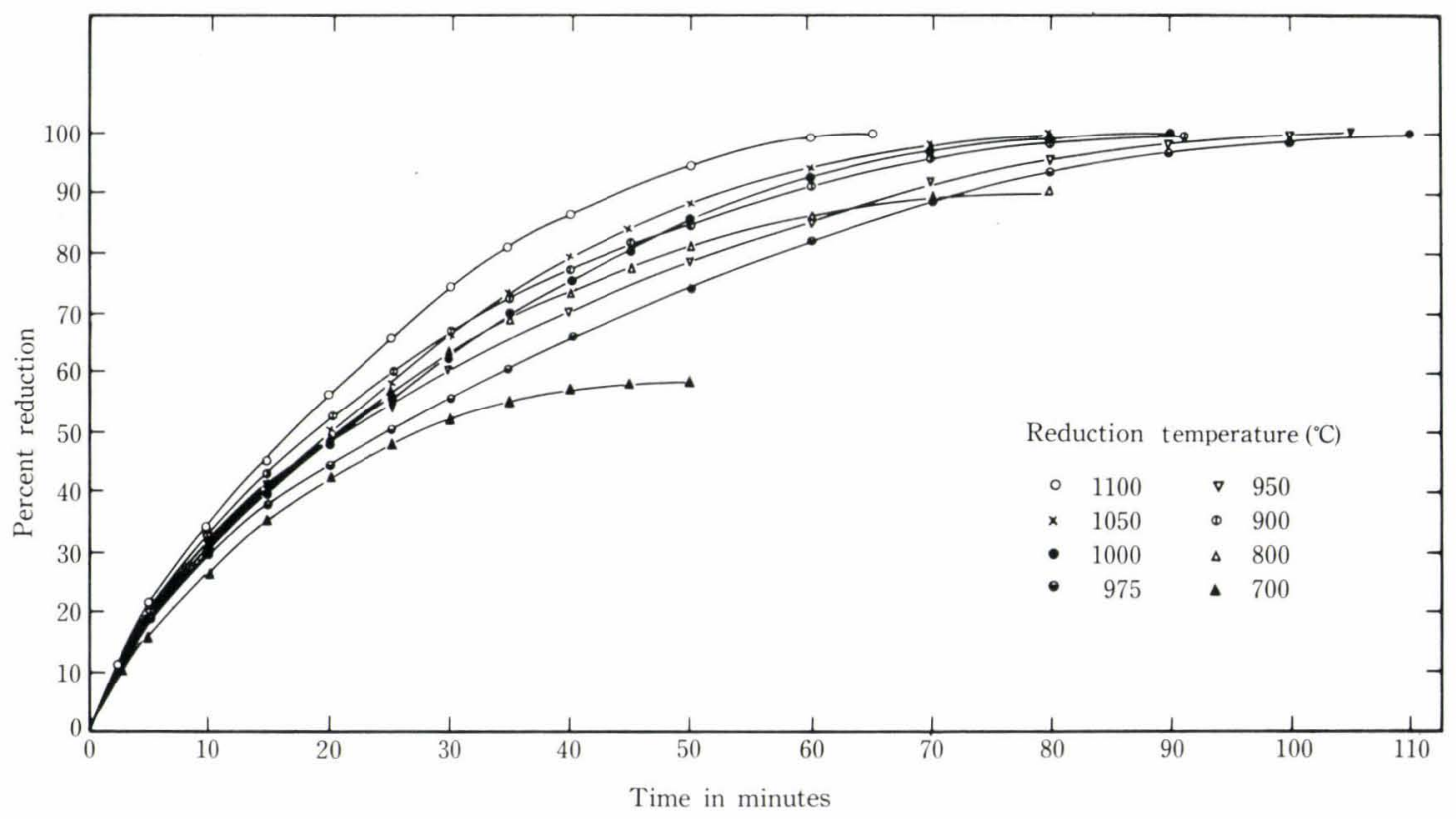

Fig. 5. Reduction curves of porous briquettes with $\mathrm{CO}$

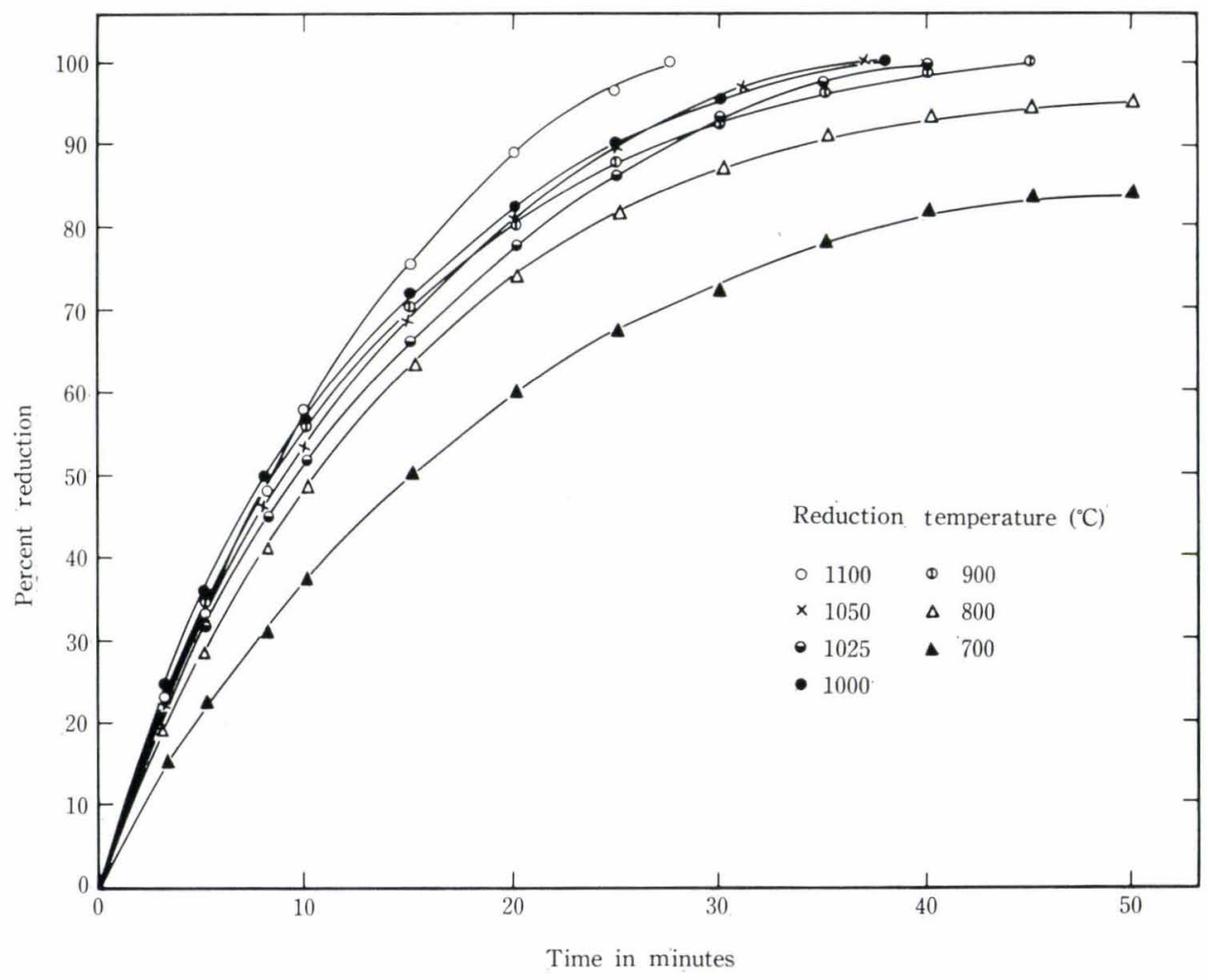

Fig. 6. Reduction curves of porous briquettes with a $50 \% \mathrm{CO} / \mathrm{H}_{2}$ mixture 


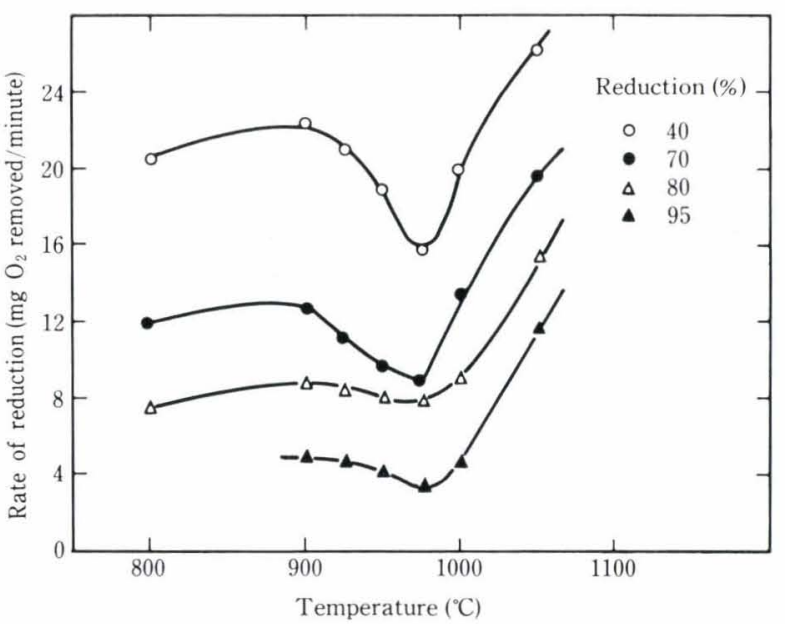

Fig. 7. Effect of temperature on the rate of reduction of porous briquettes with $\mathrm{CO}$

some reduction curves overlap each other at certain temperatures. By plotting the rates of reduction against temperature it indicates a rate minimum at $975^{\circ} \mathrm{C}$ for $\mathrm{CO}$ reduction (Fig. 7) and another minimum at $1025^{\circ} \mathrm{C}$ for reduction with $\mathrm{CO} / \mathrm{H}_{2}$ mixtures (Fig. 8).

\section{Effect of Temperature on the Reduction Rate}

Arrhenius plots for reduction of porous briquettes were made and the activation energy values were given in Table 4. The values are much lower than those obtained for dense briquettes but vary also with gas composition.

\section{Microscopic Examination}

Porous briquettes show more diffuse reaction zones than dense briquettes; also two iron zones were observed for reduction with $\mathrm{CO}$ and $\mathrm{CO} / \mathrm{H}_{2}$ mixtures. At the rate minimum temperature most of the wustite particles were entrapped inside iron shells (Photo. 2). Above or below the rate minimum temperature the wustite iron intergrowth does not show such isolated wustite areas (Photo. 3).

\section{Mechanism of Reduction}

Activation energies for reduction of porous briquettes suggest a gaseous diffusion controlled reac$\operatorname{tion}^{34)}$ for all gases used. Due to fast chemical reaction

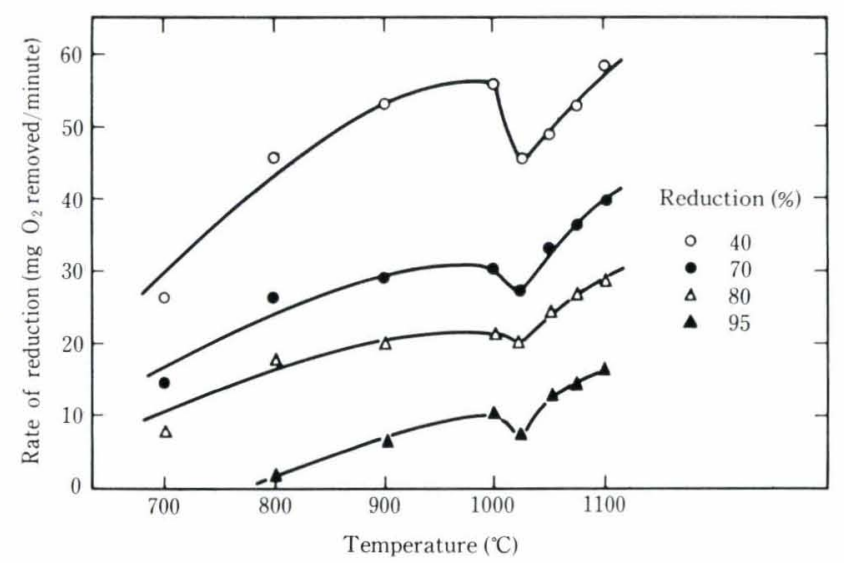

Fig. 8. Effect of temperature on the rate of reduction of porous briquettes with a $50 \% \mathrm{CO} / \mathrm{H}_{2}$ mixture
Table 4. Activation energies for reduction of porous briquettes

\begin{tabular}{c|c}
\hline Reducing gas & $E(\mathrm{kcal} / \mathrm{mol})$ \\
\hline $100 \% \mathrm{CO}$ & 2.28 \\
$75 \% \mathrm{CO}+25 \% \mathrm{H}_{2}$ & 3.00 \\
$50 \% \mathrm{CO}+50 \% \mathrm{H}_{2}$ & 3.66 \\
$25 \% \mathrm{CO}+75 \% \mathrm{H}_{2}$ & 4.11 \\
$100 \% \mathrm{H}_{2}$ & 5.14 \\
\hline
\end{tabular}

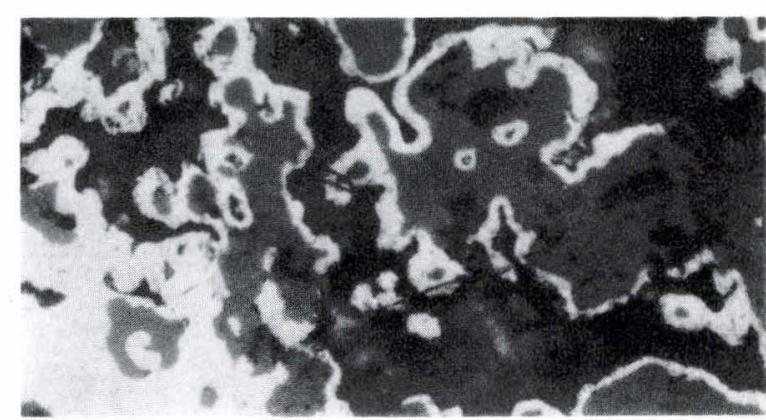

Photo. 2. Photomicrograph of porous briquette, $60 \%$ reduced with $\mathrm{CO}$ at $975^{\circ} \mathrm{C}(\times 1800)(\times 4 / 5)$

rates of porous briquettes, the rate of gaseous diffusion through the briquette became the slowest step. At the rate minima temperatures, which are rather high, sintering of iron (or iron carbide) around wustite grains isolated them from direct contact with the reducing gas and hence hinders reduction rate.

Reduction with $\mathrm{CO} / \mathrm{H}_{2}$ mixtures does not significantly vary from $\mathrm{CO}$ reduction except for a $50^{\circ} \mathrm{C}$ shift in the rate minimum temperature. This is most probably due to the fact that the amount of iron carbide formed during $\mathrm{CO}$ reduction is greater than that formed in case of $\mathrm{CO} / \mathrm{H}_{2}$ mixtures, and allows the same degree of sintering at a lower temperature in the former case.

\section{Correlation of Activation Energy with Gas Composition}

From Tables 3 and 4, it is interesting to find a linear relation between the activation energy of reduction and the corresponding gas composition as shown in Fig. 9. From these lines, the activation energy $E_{m}$ corresponding to a certain gas mixture $X_{\mathrm{H}_{2}}$ (for example) could be represented by;

$$
E_{m}=E_{\mathrm{CO}}+b X_{\mathrm{H}_{2}}
$$

where, $E_{\mathrm{CO}}$ : the activation energy for reduction with pure $\mathrm{CO}$

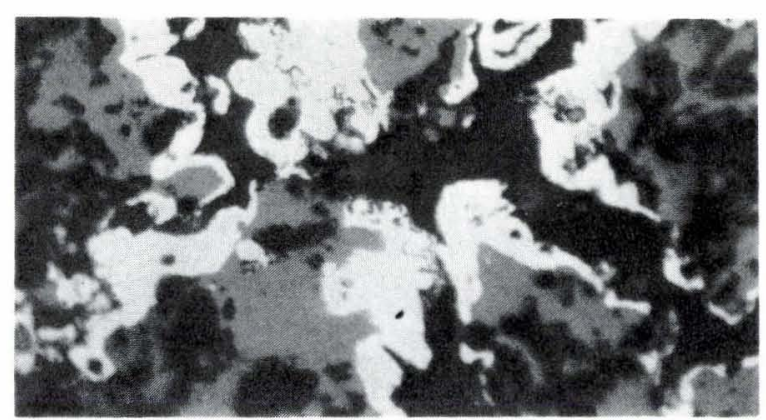

Photo. 3. Photomicrograph of porous briquette, $60 \%$ reduced with $\mathrm{CO}$ at $1100^{\circ} \mathrm{C}(\times 1800)(\times 4 / 5)$ 


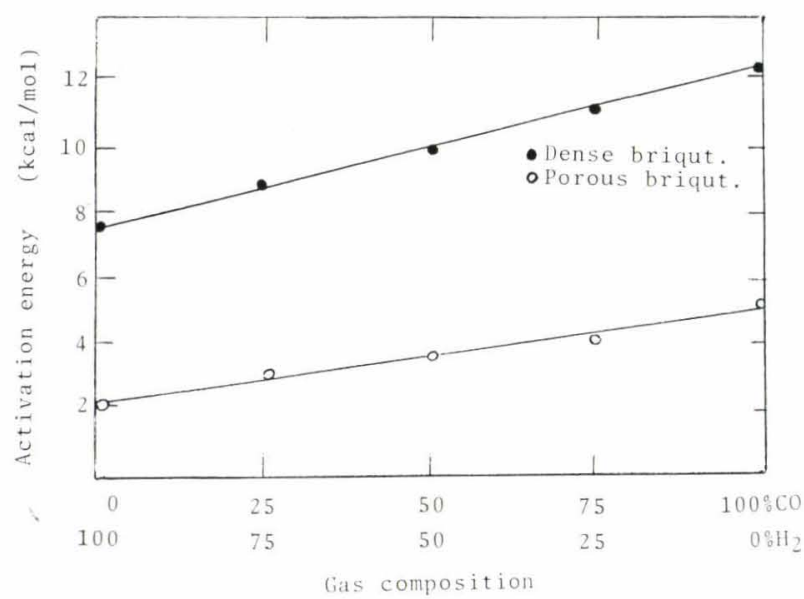

Fig. 9. Relation between reducing gas composition and the activation energy of reduction.

$b$ : a constant representing the slope of the line.

A similar expression could be written in terms of the $\mathrm{CO}$ ratio in the gas mixture.

Substituting for the values of $E_{m}$ and $E_{\mathrm{CO}}$ in Eq.

(1), from the Arrhenius form;

$$
K=A e^{-E / R T}
$$

we finally get;

$$
K_{m}=K_{\mathrm{CO}} \cdot A_{m} / A_{\mathrm{CO}} \mathrm{e}^{-b X_{\mathrm{H}_{2}} / R T}
$$

where, $K_{m}$ and $K_{\mathrm{CO}}$ : the reaction rate constants for a certain gas mixture and pure $\mathrm{CO}$ respectively

$A_{m}$ and $A_{\mathrm{CO}}$ : the corresponding constants of the Arrhenius relation.

From Eq. (3) the reaction rate constant $K_{m}$ varies exponentially with the corresponding gas composition $X_{\mathrm{H}_{2}}$, provided that all other factors are constant. Actually, $K_{\mathrm{CO}}$ and $A_{\mathrm{CO}}$ are constants for pure CO, and $A_{m}$ is found to be constant in the range of gas compositions used (plotting $\log K_{m}$ vs. $X_{\mathrm{H}_{2}}$ gives straight line).

\section{Carbon Deposition}

$\mathrm{X}$-ray analysis of reduced briquettes revealed the presence of iron carbide and free carbon up to $900^{\circ} \mathrm{C}$, while at higher temperatures only iron carbide is detected. Tables 5 and 6 represent carbon analysis and the phases present in reduced samples. However, iron carbide which was microscopically detected may be formed in one of the following ways:

(1) Below $900^{\circ} \mathrm{C}$, fine deposited carbon (2CO $\rightleftharpoons \mathrm{CO}_{2}+\mathrm{C}$ ) reacts with freshly formed iron to give iron carbide. Solid-state solubility of carbon in iron depends mainly on temperature. The most favourable factor is the size of carbon atoms as compared with that of iron which enables the former to enter the octahedral holes of the iron lattice. ${ }^{35)}$

(2) Above $900^{\circ} \mathrm{C}$, carborization of the reduced iron by the reaction $3 \mathrm{Fe}+2 \mathrm{CO}=\mathrm{Fe}_{3} \mathrm{C}+\mathrm{CO}_{2}$ occurs. ${ }^{35}$ )

The values listed in Tables 5 and 6 indicate that the amounts of carbon deposited during reduction de-
Table 5. X-ray and carbon analysis for reduced dense briquettes

\begin{tabular}{c|l|rrr}
$\begin{array}{c}\text { Temp. } \\
\left({ }^{\circ} \mathrm{C}\right)\end{array}$ & $\begin{array}{c}\text { Reduc- } \\
\text { ing } \\
\text { gas }^{*}\end{array}$ & $\begin{array}{c}\text { Reduc- } \\
\text { tion } \\
(\%)\end{array}$ & $\begin{array}{c}\text { Total } \\
\text { carbon } \\
(\%)\end{array}$ & \multicolumn{1}{c}{ Phases present } \\
\hline 700 & $\mathrm{CO}$ & 42 & 2.10 & $\mathrm{Fe}_{3} \mathrm{O}_{4}, \mathrm{FeO}, \alpha-\mathrm{Fe}, \mathrm{Fe}_{3} \mathrm{C}, \mathrm{C}$ \\
& $\mathrm{CO} / \mathrm{H}_{2}$ & 65 & 0.82 & $\mathrm{Fe}_{3} \mathrm{O}_{4}, \mathrm{FeO}, \alpha-\mathrm{Fe}, \mathrm{Fe}_{3} \mathrm{C}, \mathrm{C}$ \\
\hline 800 & $\mathrm{CO}$ & 85 & 1.63 & $\mathrm{FeO}, \alpha-\mathrm{Fe}, \mathrm{Fe}_{3} \mathrm{C}, \mathrm{C}$ \\
& $\mathrm{CO} / \mathrm{H}_{2}$ & 92 & 0.49 & $\mathrm{FeO}, \alpha-\mathrm{Fe}, \mathrm{Fe}_{3} \mathrm{C}, \mathrm{C}$ \\
\hline \multirow{2}{*}{900} & $\mathrm{CO}$ & 100 & 0.85 & $\alpha-\mathrm{Fe}, \mathrm{Fe}_{3} \mathrm{C}, \mathrm{C}$ \\
& $\mathrm{CO} / \mathrm{H}_{2}$ & 100 & 0.40 & $\alpha-\mathrm{Fe}, \mathrm{Fe}_{3} \mathrm{C}, \mathrm{C}$ \\
\hline 1000 & $\mathrm{CO}$ & 100 & 0.51 & $\alpha-\mathrm{Fe}, \mathrm{Fe}_{3} \mathrm{C}$ \\
& $\mathrm{CO} / \mathrm{H}_{2}$ & 100 & 0.12 & $\alpha-\mathrm{Fe}, \mathrm{Fe}_{3} \mathrm{C}$ \\
\hline \multirow{2}{*}{1100} & $\mathrm{CO}$ & 100 & 0.25 & $\alpha-\mathrm{Fe}, \mathrm{Fe}_{3} \mathrm{C}$ \\
& $\mathrm{CO} / \mathrm{H}_{2}$ & 100 & 0.03 & $\alpha-\mathrm{Fe}, \mathrm{Fe}_{3} \mathrm{C}$
\end{tabular}

* Mixtures are $50 \%$ of both gases.

Table 6. X-ray and carbon analysis for reduced porous

\begin{tabular}{|c|c|c|c|c|}
\hline $\begin{array}{c}\text { Temp. } \\
\left({ }^{\circ} \mathrm{C}\right)\end{array}$ & $\begin{array}{l}\text { Reduc- } \\
\text { ing } \\
\text { gas* }\end{array}$ & $\begin{array}{c}\text { Reduc- } \\
\text { tion } \\
(\%)\end{array}$ & $\begin{array}{c}\text { Total } \\
\text { carbon } \\
(\%)\end{array}$ & Phases present \\
\hline \multirow[t]{2}{*}{700} & $\mathrm{CO}$ & 60 & 1.70 & $\mathrm{Fe}_{3} \mathrm{O}_{4}, \mathrm{FeO}, \alpha-\mathrm{Fe}, \mathrm{Fe}_{3} \mathrm{C}, \mathrm{C}$ \\
\hline & $\mathrm{CO} / \mathrm{H}_{2}$ & 80 & 1.25 & $\mathrm{FeO}, \alpha-\mathrm{Fe}, \mathrm{Fe}_{3} \mathrm{C}, \mathrm{C}$ \\
\hline \multirow[t]{2}{*}{800} & $\mathrm{CO}$ & 88 & 1.52 & $\mathrm{FeO}, \alpha-\mathrm{Fe}, \mathrm{Fe}_{3} \mathrm{C}, \mathrm{C}$ \\
\hline & $\mathrm{CO} / \mathrm{H}_{2}$ & 95 & 0.91 & $\mathrm{FeO}, \alpha-\mathrm{Fe}, \mathrm{Fe}_{3} \mathrm{C}, \mathrm{C}$ \\
\hline \multirow[t]{2}{*}{900} & $\mathrm{CO}$ & 100 & 0.65 & $\alpha-\mathrm{Fe}, \mathrm{Fe}_{3} \mathrm{C}, \mathrm{C}$ \\
\hline & $\mathrm{CO} / \mathrm{H}_{2}$ & 100 & 0.32 & $\alpha-\mathrm{Fe}, \mathrm{Fe}_{3} \mathrm{C}, \mathrm{C}$ \\
\hline $975 * *$ & $\mathrm{CO}$ & 100 & 0.89 & $\alpha-\mathrm{Fe}, \mathrm{Fe}_{3} \mathrm{C}, \mathrm{C}$ \\
\hline \multirow[t]{2}{*}{1000} & $\mathrm{CO}$ & 100 & 0.48 & $\alpha-\mathrm{Fe}, \mathrm{Fe}_{3} \mathrm{C}$ \\
\hline & $\mathrm{CO} / \mathrm{H}_{2}$ & 100 & 0.21 & $\alpha-\mathrm{Fe}, \mathrm{Fe}_{3} \mathrm{C}$ \\
\hline $1025 * *$ & $\mathrm{CO} / \mathrm{H}_{2}$ & 100 & 0.37 & $\alpha-\mathrm{Fe}, \mathrm{Fe}_{3} \mathrm{C}$ \\
\hline \multirow[t]{2}{*}{1100} & $\mathrm{CO}$ & 100 & 0.13 & $\alpha-\mathrm{Fe}, \mathrm{Fe}_{3} \mathrm{C}$ \\
\hline & $\mathrm{CO} / \mathrm{H}_{2}$ & 100 & 0.06 & $\alpha-\mathrm{Fe}, \mathrm{Fe}_{3} \mathrm{C}$ \\
\hline
\end{tabular}
briquettes

* Mixtures are $50 \%$ of both gases.

** Rate minimum temperature

crease with both rise in temperature and the presence of hydrogen.

In direct reduction processes where the degree of metallization does not usually exceed 95 to $96 \%$, the carbon deposited on pellets acts as reducing agent for the remaining oxides during smelting for steelmaking. It is also an advantage in steelmaking if the charged materials already contain sufficient carbon as iron carbide to produce specific steel grades. Carburization could be controlled by adjusting both the reduction temperature and the gas composition to maintain the carbon content of the metallized material within certain limits.

\section{Summary and Conclusions}

The reduction mechanism of pure $\mathrm{Fe}_{2} \mathrm{O}_{3}$ briquettes with $\mathrm{CO} / \mathrm{H}_{2}$ mixtures was found to depend on the 
original structure (porosity and grain size) as well as the reducing gas composition. These factors significantly affect the structure of the phases formed during reduction.

Reduction of dense briquettes with $\mathrm{H}_{2}$ is chemically controlled at the initial stages, and becomes mixed controlled by both the chemical reaction and gaseous diffusion for reduction with either $\mathrm{CO}$ or $\mathrm{CO} / \mathrm{H}_{2}$ mixtures, with more contribution of the gaseous diffusion part as $\mathrm{CO}$ ratio in the gas increases. The rates of reduction with $\mathrm{CO}$ are much slower than those with $\mathrm{H}_{2}$, and are intermediate for gas mixtures. Chemical rates predominate for reduction with $\mathrm{H}_{2}$, but due to the formation of a porous iron carbide layer during reduction with $\mathrm{CO}$, it causes a diffusional resistance for gases which contributes to the overall rate.

Reduction of porous briquettes is gaseous diffusion controlled for all gases.

The activation energy of reduction varied linearly with gas composition, while the overall reduction rates exponentially varied with gas composition.

\section{REFERENCES}

1) N. J. Themelis and W. H. Gauvin: Can. Min. Met. Bull., 444, (1962), July.

2) L. V. Bogdandy, H. P. Schültz, L. N. Stranski and B. Würzner: Bunsengessellschaft für Phys. Chem., 67 (1963), 958.

3) H. Schenck and H. P. Schültz: Arch. Eisenhüttemw., 31 (1960), 691 .

4) L. V. Bogdandy and W. Jank: Z. Elektrochem., Ber. Bunsenges. phys. Chem., 61 (1957), 1146.

5) H. K. Kohl and H.S. Engell: Arch. Eisenhüttenw., 34 (1963), 411 .

6) E. Kawasaki, J. Sanscrainte and T. Walash: J. Amer. Inst. Chem. Eng., 8 (1962), 48.

7) R. G. Olsson and W. M. McKewan: Trans. Met. Soc. AIME, 236 (1966), 1518.

8) W-K Lu: Trans. Met. Soc. AIME, 227 (1963), 203.

9) W-K Lu and G. Bitsiances: Trans. Met. Soc. AIME, 236 (1966), 531 .

10) M. H. Davis, M. T. Simnad and C. E. Birchnall: Trans. Met. Soc. AIME, 191 (1951), 889.
11) L. Himmel, R. F. Mehl and C. E. Birchnall: J. Metals, 5 (1953), 827.

12) J. O. Edström: Jernkont. Ann., 141 (1957), 809.

13) I. G. Dalla Lana and N. R. Amundson: Ind. Eng. Chem., 53 (1961), 22.

14) N. J. Themelis and W. H. Gauvin: Trans. Met. Soc. AIME, 227 (1963), 290.

15) B.B.L. Seth and H. U. Ross: Cand. Met. Quart., 5 (1966), 315.

16) B.B.L. Seth: JISI, 207 (1969), 1104.

17) P.F.J. Landler and K. H. Komarek: Trans. Met. Soc. AIME, 236 (1966), 138.

18) Y. Hara, M. Tsuchiya and S. Kondo: Trans. ISIJ, 12 (1972), 223.

19) Y. Hara, T. Aida and S. Kondo: J. Japan Inst. Metals, 31 (1967), 987.

20) A. K. Lahiri: JISI, 206 (1968), 725.

21) N. A. Oates and D. D. Todd: J. Aus. Inst. Met., 7 (1962), 109.

22) S. E. Khalafalla and P. L. Weston: Trans. Met. Soc. AIME, 239 (1967), 1494.

23) T.J.J. Smith, W. R. Maddocks and E. W. Nixon: 9th Commonwealth Mining and Metallurgical Congress, England, 1969, Inst. Mining \& Metallurgy, ed., (1970), 313.

24) J. Jindrich: Hutn. Listy, 25 (1970), No. 4, 211.

25) B. Stalhane and T. Malmberg: Jernkont. Ann., 113 (1930), 93.

26) M. Wiberg: Disc. Farad. Soc., (1948), No. 4, 231.

27) E. S. Vorentsov and A. V. Ermakov: Izvest. An. Met. Gornoye Delo, 5 (1963), 23.

28) V. K. Simonov, L. N. Rodenko and S. T. Rostovetsev: Met. Koksokhim, (1968), No. 13, 3.

29) L. V. Bogdandy: Stahl u. Eisen, 82 (1962), 869.

30) A. Domsa, L. Szabo, Z. Sparchez and A. Palfalvy: Intn'l Powder Metallurgy Conf., New York, June, (1965), 14.

31) K. A. Shehata and S. Y. Ezz: Trans. Inst. Min. Met., 82 (1973), C38.

32) J. F. Elliott and M. Gleiser: Thermochemistry of Steelmaking, Addison-Wesely, (1960).

33 E. T. Turkdogan and J. V. Vinters: Met. Trans. AIME, 3 (1972), 1561.

34) P. K. Strangway: Thesis for the degree Master of Science, Dept. Met. Mater. Sci., Univ. of Toronto, (1964).

35) H. Schenck, N. G. Schmahl and A. K. Biswas: Arch. Eisenhüttenw., 28 (1957), 517. 